in as imports from Europe in the form of shooks, battens and metal fittings, put together to form the chest on the spot.

This century has witnessed the advent of plywood and revolutionized the construction of the tea chests. In Indian Forest Records (New Series: Utilisation, Vol. 3, No. 4, Forest Research Institute, Dehra Dun, 1945), Mr. V. D. Limaye deals with "The Testing of Indian Plywood Tea Chests" with the object of establishing a standard type. With this objective in view, nine different types of plywood tea chests were subjected to systematic scientific tests at the Timber Testing Laboratory, with the view of establishing a standard tea chest of Indian make, comparable with the best of foreign makes. In India, plywood tea chests are manufactured from various timbers such as hollock (Terminalia myriocarpa), hollong (Dipterocarpus macrocarpus), mango (Mangifera indica), semul (Bombax malabaricum), pali, and others. Hollock is the main source of supply. It grows in the forests of Assam.

In the past, boxes of all these timbers have been subjected to systematic research at Dehra Dun. The series of exhaustive tests here described was carried out on nine different types of tea chests, known as the ' $O$ ', ' $S$ ' and ' $M$ ' types made chiefly of hollock timber with the view of analysing their comparative merits, and establishing a standard type of Indian plywood tea chest comparable with the best foreign makes. It would appear that this object has been fulfilled and that in this respect India at last can be considered as no longer dependent on imports. Boxes of each of the nine types, totalling in all 210, and representative of the average quality produced by the mill, were supplied in shook form by the Assam Saw Mills. The most common size of box, namely, 19 in. $\times 19$ in. $\times 24$ in., was chosen for the tests. In each of the ' $O$ ' and ' $S$ ' types, boxes of sizes 14 in. $\times$ 14 in. $\times 14$ in., 16 in. $\times 16$ in. $\times 16$ in., 18 in. $\times$ 18 in. $\times 18$ in., 18 in. $\times 12$ in. $\times 18$ in. were tested, the thickness of the veneers varying. In the ' $O$ ' type the plywood was all hollock. In the ' $S$ ' type the outside ply is of hollong (Dipterocarpus macrocarpus). In the ' $M$ ' type the outer ply is of semul. Boxes made with the side panels with the grain vertical are the strongest.

Summarizing the research work the following results are given : The ' $O$ ', 14 in. $\times 14$ in. $\times 14$ in., and ' $S$ ', 14 in. $\times 14$ in. $\times 14$ in., types of plywood tea-chest are found to be very much stronger than the average of the best five makes of imported birch tea-chests, taken as the datum for comparison. By reducing the thickness of plywood to $3 / 16$ in., it has been found that the cost of a tea-chest can be reduced, owing to economy in timber, without sacrificing the strength required. 18 in. $\times 12$ in. $\times 18$ in. type and 16 in. $\times 16$ in. $\times 16$ in. type are both comparable to the datum birch tea-chests; but the 18 in. $\times 12$ in. $\times 18 \mathrm{in}$. type is found to be slightly stronger than the 16 in. $\times 16$ in. $\times 16$ in. type, probably due to a more balanced construction of plywood. The teachest of ' $O$ ', 18 in. $\times 12$ in. $\times 18$ in. type, is, therefore, recommended as a standard, if making veneers of two different thicknesses is not considered a great disadvantage from the manufacturer's point of view. If 18 in. $\times 12$ in. $\times 18$ in. type is not considered convenient, then 16 in. $\times 16$ in. $\times 16$ in. type, which is the next best, can be established as the standard. There is no difference of any practical importance between the ' $O$ ' and ' $S$ ' types so far as strength is concerned.

\section{JOHN INNES HORTICULTURAL INSTITUTION}

$\mathrm{T}$ HERE is nothing merely formal or perfunctory, and much that is challenging, in the thirty-fifth annual report, for 1944, of the John Innes Horticultural Institution (from the Institution, Mostyn Road, Merton Park, London, S.W.19. 1945). Dr. C. D. Darlington, director of the Institution, has recently enunciated the hypothesis that "viruses of specific types can be created by grafting particular pairs of individuals". This is based on M. B. Crane's experiments on grafting the apple variety, Lord Lambourne, with other varieties. Lambourne may then become infected with two abnormalities'rubbery wood' and 'chat fruit'-deemed to be viruses. From the evidence presented in the report, it would seem that such infection could be explained by the assumption that Lambourne is completely susceptible to the two viruses, for which most apple varieties are symptomless carriers. The assumption that viruses are 'created' by the graft union seems at least a little ahead of the facts.

Mr. Crane and Dr. Lewis make the interesting suggestion of raising hybrid raspberries from seed, in order to eliminate virus from the initial stock. Preliminary experiments show satisfactory yields from hybrids, but many facets of the problem require consideration before hybrid seedling production can be regarded as a commercial proposition.

Dr. P. T. Thomas has found that 'bolters' in the potato crop possess an extra chromosome fragment which may presumably account for their premature flowering. Statistical technique has been applied by Dr. K. Mather to the analysis of behaviour and organization of polygenes. This provides more exact equipment for the plant breeder, and makes it possible to predict minimal selective limits, to relate the actual number of genes to their observed expression, and to determine whether hybrid vigour has reached the maximum.

The Institution has adopted the title, "Answers to Growers", for its first Bulletin (price 2s. 6d. from the Institution). Growers appear to have left the Institution in no doubt of their needs and, if their questions are such as to epitomize the work of the John Innes at present, that selection only allows of more factual and experimental answers. The grower is told that hoeing is of value for weed control rather than for moisture conservation; that composting tomato haulms does not destroy any virus they may carry; that the ultimate behaviour of his plants depends a good deal upon the character of the compost used for raising seedlings. Questions about the practical culture of sweet corn are answered. The particular and complex methods of hybrid seed production of this crop by top-crosses, double- and three-way crosses, and by synthetic varieties, are explained. The question, 'What are the best plums to grow ?', is answered by stating general principles - correct interplanting of dessert kinds (which are self- and cross-incompatible), the separation of highnectar varieties from those with low nectar, and the choice of frost-free sites, as plums flower early in the season. Some varieties of apple are shown to resist attack by red spider.

The Bulletin has achieved the right practical tone ; it is well produced, with a general series of photographs of experiments at the Institute, and the identity of the contributors is but thinly veiled by their initials. 